\title{
Enhanced cadmium removal by growing Bacillus cereus RC-1 immobilized on different magnetic biochars through simultaneous adsorption and bioaccumulation
}

\section{Min Deng}

Shenzhen Prevention and Treatment Center for Occupational Diseases

Kai Li

South China Agricultural University

Yu-Jian Yan

South China Agricultural University

Fei Huang

South China Agricultural University

Dan Peng ( $\sim$ pengdan987@hotmail.com )

Shenzhen Institute of Information Technology https://orcid.org/0000-0001-7559-4411

\section{Research Article}

Keywords: Biosorbent preparation, Heavy metal, Magnetic biochar, Microorganism immobilization, Biosorption mechanisms

Posted Date: June 18th, 2021

DOI: https://doi.org/10.21203/rs.3.rs-631344/v1

License: (c) (1) This work is licensed under a Creative Commons Attribution 4.0 International License. Read Full License

Version of Record: A version of this preprint was published at Environmental Science and Pollution Research on October 24th, 2021. See the published version at https://doi.org/10.1007/s11356-02117125-x. 


\section{Abstract}

Biosorption of cadmium by growing bacteria immobilized on the three magnetic biochars derived from rice straw (MRSB-pellet), sewage sludge (MSSB-pellet), and chicken manure (MCMB-pellet) was investigated, respectively. Total biosorption capacity of the pellets was tested under varying range of $\mathrm{pH}$, culture time, and initial $\mathrm{Cd} 2+$ concentration. The maximum biosorption capacity of $93.02 \mathrm{mg} / \mathrm{g}$ was obtained with MRSB-pellet, followed by MSSB-pellet $(68.02 \mathrm{mg} / \mathrm{g})$ and MCMB-pellet $(63.95 \mathrm{mg} / \mathrm{g})$. The biosorption by these immobilized bacterial pellets was more effective than free bacteria, this enhancement could be the result of simultaneous adsorption and bioaccumulation, mainly resulting from magnetic biochar carrier and active bacteria, respectively. The biosorption process by immobilized pellets was primarily driven by ion-exchange and complexation, which jointly contributed of $73.56 \%$ (MRSBpellet) to $78.62 \%$ (MSSB-pellet) the total adsorption, while the mechanisms of chemical precipitation and physical adsorption could averagely contribute 6.91\% (MSSB-pellet) and 11.24\% (MRSB-pellet), respectively. Intracellular accumulation was comparably tiny among these mechanisms accounting for 4.30-5.92\% of total biosorption, in turn, it would maintain intracellular $\mathrm{Cd} 2+$ concentration below a toxic threshold to promote cell growth. These suggested that magnetic biochar immobilized bacteria, particularly MRSB-pellet could be used as an effective biosorbent to remove the $\mathrm{Cd} 2+$ from the growth medium. This study further deepened our understanding of biosorption process by microorganism immobilized onto magnetic biochar for the metals removal.

\section{Introduction}

Cadmium (Cd), one of the most common toxic heavy metals in wastewater, which poses the severe risk to human health even at low concentrations of 0.001-0.1 mg/L, including kidney, bone and pulmonary damages (Godt et al., 2006). Large quantities of the wastewater containing $\mathrm{Cd}^{2+}$ are introduced into the environment from industrial activities, such as mining, refining, plastic manufacturing, and electroplating. Accordingly, chemical techniques including precipitation, coagulation, ion-exchange, membrane processing, and solvent extraction have been applied to remove Cd pollutants from wastewater (Huang et al., 2013). While biological method using bacteria, fungus, yeast, and microalgae, has been recently recognized as a more economic and effective technology for the metal removal (Tsekova et al., 2010; Huang et al., 2014; Khan et al., 2016; Shen et al., 2018). In this context, immobilized microbial cell rather than free cell has multitude advantages to treat wastewater, such as stronger resistance to environmental perturbations and toxic chemicals, higher microbial number and activity, and greater efficiency of cell recovery and reuse (Zamani et al., 2018).

Many scientists have investigated systematically the environmental application of immobilized microorganism to the $\mathrm{Cd}^{2+}$ removal from aqueous solutions (Tsekova et al., 2010; Piccirillo et al., 2013; Ma et al., 2015). These studies and other investigations (Li et al., 2017; Shen et al., 2018; Liu et al., 2019) have demonstrated that immobilized microorganism has greater biosorption capacity of $\mathrm{Cd}^{2+}$ than free microorganism to some extent, in which the life-form of immobilized microorganism was always dead or resting state. To date, few studies have examined the biosorption by immobilized growing microorganism 
(metabolic cells) to remove $\mathrm{Cd}^{2+}$ from aqueous solutions. This is probably because the biosoprtion process of immobilized metabolic cell is more complicated than that of immobilized dead cell, where the dynamic change of metabolic cells in the biosorption, posing the challenges for understanding the biosorption mechanisms. In fact, the direct use of metabolic cells for metal removal could simplify control system and reduce operation costs, by avoiding the need for a separate biomass production process including cultivation, harvest, dry, process and storage prior to use (Chojnacka, 2010). Therefore, the immobilization of metabolic cells might provide a potential alternative for heavy metals bioremediation.

Immobilization carriers mainly include sodium alginate, polysulfone, and polyurethane, which have been applied for the entrapment of microorganism to enhance bioremediation efficiency (Tsekova et al., 2010; Barquilha et al., 2017). Compared with these materials, magnetic biochar used as microbial carrier could provide habitats for growing microbes because of large specific surface areas, thereby improving cell viability to enhance the overall biosorption of heavy metals (Zhu et al., 2017). Owing to the fact that magnetic biochar is easily separated from the solutions, it is ideally suited for the immobilization of metabolic cells to remove toxic metals from liquid medium.

The mechanisms of metal biosorption by immobilized bacterial pellet could be generally classified into two groups, namely adsorption and bioaccumulation (Robalds et al., 2016). The immobilized pellet is composed of growing microorganism and supporting matrix, during which actively growing cells could remove metal ions either by active adsorption onto cell surface or sequestration in cell cytoplasm (intracellular accumulation), whereas magnetic biochar could only remove heavy metals by passive adsorption. Specifically speaking, the overall biosorption mechanisms responsible for the $\mathrm{Cd}^{2+}$ removal include : (i) physical adsorption of $\mathrm{Cd}^{2+}$ was resulted from the electrostatic and van der Waals interactions (Sohbatzadeh et al., 2017); (ii) ion-exchange of $\mathrm{Cd}^{2+}$ with positively charged ions such as $\mathrm{K}^{+}$, $\mathrm{Ca}^{2+}, \mathrm{Na}^{+}$and $\mathrm{Mg}^{2+}$ (Markou et al., 2015); (iii) complexation of $\mathrm{Cd}^{2+}$ with functional groups (e.g., - $\mathrm{OH},-$ $\mathrm{COOH}$ ) and $\mathrm{C} \pi$ electrons (e.g., $\mathrm{C}=\mathrm{C}, \mathrm{C}=\mathrm{N}$ ) (Gao et al., 2019); (iv) precipitation of $\mathrm{Cd}^{2+}$ with $\mathrm{OH}^{-}, \mathrm{PO}_{4}{ }^{3-}$, $\mathrm{CO}_{3}{ }^{2-}$, and $\mathrm{SiO}_{3}{ }^{2-}$ (Huang et al., 2020a). Owing to the coincidence of these mechanisms in bacteria and biochar (active or passive adsorption), it is impossible to determine whether involved mechanisms are derived from microbial cell or biochar matrix. While the remaining mechanism is intracellular accumulation (bioaccumulation) was only resulted from bacteria, in which the bioaccumulation capacity of $\mathrm{Cd}^{2+}$ would determine whether the bacterial cells are live or die. Despite the previous works, there is a lack of quantitative information regarding on the relative distribution of mechanisms involved in total metal biosorption process by immobilized pellet, which we assessed for immobilized growing bacterial cells using different magnetic biochars derived from rice straw, sewage sludge and chicken manure, respectively.

To summarize, three objectives of this study are: (i) to search for an effective and environmental friendly method to immobilize growing bacterial cells on the magnetic biochar by the optimization of preparation and biosorption conditions; (ii) to assess the biosorption characterization of $\mathrm{Cd}^{2+}$ by growing cells 
immobilized on different magnetic biochars, and the comparison between immobilized bacteria and free bacteria; (iii) to investigate the relative contributions of involved mechanisms to total biosorption qualitatively and quantitatively. This could provide insights into the biosorption process of $\mathrm{Cd}^{2+}$ by immobilized microorganism pellet, which is an important step towards possible metal bioremediation.

\section{Materials And Methods}

\subsection{The preparation of magnetic pellet}

Bacillus cereus RC-1, a spore-forming and rod-shaped bacterium, which was isolated from heavy metalcontaminated soil, Guangzhou, China. The bacterial strain was grown in a nutrient broth medium containing peptone $(10 \mathrm{~g} / \mathrm{L})$, beef extract $(3 \mathrm{~g} / \mathrm{L})$ and sodium chloride $(5 \mathrm{~g} / \mathrm{L})$ with pH $7.4 \pm 0.2$ at $28 \pm 2$ ${ }^{\circ} \mathrm{C}$ (Huang et al., 2013). Magnetic biochar was prepared by the methods previously described by Huang et al. (2021). The mixed solution of $\mathrm{FeCl}_{3} \cdot 6 \mathrm{H}_{2} \mathrm{O}$ and $\mathrm{FeSO}_{4} \cdot 7 \mathrm{H}_{2} \mathrm{O}$ was added into deionized water and stirred until they were dissolved completely, then the powdered biomass was mixed with the solutions and stirred at room temperature $\left(25 \pm 2^{\circ} \mathrm{C}\right)$ for $20 \mathrm{~min}$. After that, the $\mathrm{pH}$ of mixed suspension was adjusted to $10-11$ by adding $\mathrm{NaOH}$. After being stirred for $30 \mathrm{~min}$, the suspension was slowly pyrolyzed in a muffle furnace under $\mathrm{N}_{2}$ atmosphere at $600^{\circ} \mathrm{C}$ for $4 \mathrm{~h}$ according to the methods of Mohan et al. (2014). The resulting magnetic biochars from rice straw, sewage sludge, and chicken manure were named as MRSB, MSSB, and MCMB, respectively, in which their main physicochemical properties were provided in Table S1.

To obtain immobilization conditions, taking sodium alginate (SA) concentration, proportion of bacteria and $S A$, and crosslinking time as factors to design the orthogonal experiment $\left(L_{9} 3^{3}\right.$, Table $\left.S 2\right)$. Bacterial cells at exponential phase $\left(\mathrm{OD}_{600}=1.0-1.2\right)$ were inoculated into $100 \mathrm{~mL}$ of sterilized nutrient broth with known amounts of magnetic biochar and sterile $\mathrm{SA}$, and then the solution was added into sterile $\mathrm{CaCl}_{2}$ solution to produce the pellets, by dropping wise with the help of a gauge syringe (Zhang et al., 2017; Wen et al., 2018; Huang et al., 2020b). The synthesis of magnetic pellets immobilized onto MRSB, MSSB, and MCMB were hereafter referred as MRSB-pellet, MSSB-pellet, and MCMB-pellet, respectively.

\subsection{Biosorption characteristic}

The effect of initial pH on total biosorption capacity was observed in the range of 2.0-8.0, and zeta potential at different $\mathrm{pH}$ values (2.0-10.0) was also examined by the zeta meter (Malvern Nano ZS90, UK). The effect of time on total biosorption capacity, and cell number for immobilized and free bacteria were investigated at various time intervals up to $30 \mathrm{~h}$ under the three different initial $\mathrm{Cd}^{2+}$ concentrations of 20,50 and $100 \mathrm{mg} / \mathrm{L}$, respectively. The effect of initial metal concentrations on biosorption by immobilized and free bacteria was further tested in the range of $\mathrm{Cd}^{2+}$ concentrations $(5-200 \mathrm{mg} / \mathrm{L})$. Meanwhile, the cell number and ATPase activity were also determined under the metal concertation range studied, according to the methods previously reported by Luo et al. (2011). In the presence of $\mathrm{NaN}_{3}$ 
inhibition, the effect of initial metal concentrations on biosorption capacity was also examined for immobilized and free bacteria, respectively.

After the biosorption, the $\mathrm{Cd}^{2+}$ concentration in the supernatant was determined using inductively coupled plasma mass spectrometry (ICP-MS, Thermo Fisher Scientific, Waltham, MA, USA) by centrifugation $(8,000 \mathrm{rpm}, 10 \mathrm{~min})$. The values of biosorptive capacity of $\mathrm{Cd}^{2+}$ were calculated from the following equation:

where $q_{e}$ is the equilibrium $\mathrm{Cd}^{2+}$ concentration on the biosorbent $(\mathrm{mg} / \mathrm{g}), X$ is the biomass concentration $(\mathrm{g} / \mathrm{L}), C_{O}$ and $C_{e}$ are the initial and equilibrium metal concentration $(\mathrm{mg} / \mathrm{L})$, respectively.

\subsection{Biosorption mechanisms}

The biosorption by immobilized pellet was performed by adding the biosorbent into the liquid medium containing $100 \mathrm{mg} / \mathrm{L} \mathrm{Cd}^{2+}$ at room temperature and agitated at a speed of $150 \mathrm{rpm}$. The immobilized pellet sample loaded with and without $\mathrm{Cd}^{2+}$ were prepared for chemical analysis including scanning electron microscopy with energy dispersive X-ray spectroscopy (SEM-EDS, Hitachi, Japan), fourier transform infrared spectroscopy (FTIR, PerkinElmer 2000, Waltham, WA, USA), and X-ray diffractometer (XRD-6000, Shimadzu, Japan), respectively.

In order to determine the relative contribution of the involved mechanisms to total biosorption, the values of biosorptive capacity resulting from each mechanism were calculated by the modified methods of Markou et al. (2015) and Sohbatzadeh et al. (2017). After the biosorption, the immobilized pellets loaded

with $\mathrm{Cd}^{2+}$ were extracted by a step-by-step desorption of $\mathrm{ddH}_{2} \mathrm{O}, \mathrm{NH}_{4} \mathrm{NO}_{3}$, and EDTA under the initial $\mathrm{Cd}^{2+}$ concentration of 20,50 , and $100 \mathrm{mg} / \mathrm{L}$, respectively. The first fraction of $\mathrm{Cd}^{2+}$ adsorbed by physical adsorption was bound weakly, which could be desorbed by $\mathrm{ddH}_{2} \mathrm{O}\left(\mathrm{Q}_{1}\right)$. The second fraction was exchangeable with alkali metal ions such as $\mathrm{K}^{+}, \mathrm{Ca}^{2+}, \mathrm{Na}^{+}$, and $\mathrm{Mg}^{2+}$, in which the desorbent of $\mathrm{NH}_{4} \mathrm{NO}_{3}$ was a strong electrolyte to reflect the metal biosorption by ion-exchange mechanism $\left(Q_{2}\right)$. The third fraction was attributed to the complexation with functional groups from immobilized pellets $\left(Q_{3}\right)$, where EDTA- $\mathrm{Na}_{2}$ was a common chelator that could bind metal ions by this mechanism. In addition, the fraction by intracellular accumulation $\left(Q_{4}\right)$ was examined by the separation of bacterial cells from the pellets using $0.05 \mathrm{M} \mathrm{Na}_{2} \mathrm{CO}_{3}$ and $0.02 \mathrm{M}$ citric acid, as previously described by Sarma and Pakshirajan (2011). Subsequently, the determination of intracellular accumulation (bioaccumulation) by separated cells was carried out by the methods of Huang et al. (2014). Lastly, the residual fraction by precipitation $\left(Q_{5}\right)$ was calculated by subtracting the sum of $Q_{1}, Q_{2}, Q_{3}$, and $Q_{4}$ from total biosorption capacity $\left(Q_{t}\right)$. The contribution percentage of each mechanism to the overall biosorption was calculated from the following equation: 
where $Q_{i}$ is the $\mathrm{Cd}^{2+}$ biosorption capacity $(\mathrm{mg} / \mathrm{g})$ resulted from each mechanism, such as $\mathrm{Q}_{1}, \mathrm{Q}_{2}, \mathrm{Q}_{3}, \mathrm{Q}_{4}$, and $Q_{5}$, and $Q_{t}$ is the overall $\mathrm{Cd}^{2+}$ biosorption capacity $(\mathrm{mg} / \mathrm{g})$ by immobilized pellet. All the experiments were carried out in triplicate and the standard deviation is shown in the following sections. The blank control without addition of biosorbents or metal ions was conducted to exclude spontaneous precipitation or loss of $\mathrm{Cd}^{2+}$.

\section{Results And Discussion \\ 3.1. Optimization of immobilization}

Based on the orthogonal experiment results (Table 1), the optimal immobilization of pellets on MRSB (MRSB-pellet) was 3\% SA concentration, 1:1 ratio of bacteria to carrier, and crosslinking time $2 \mathrm{~h}$, in which the effect of different factors followed the order of SA concentration (Factor A) > ratio of bacteria to carrier (Factor B) > crosslinking time (Factor C), according to the Range value. These factors were also carried out to optimize immobilized condition of the pellets by magnetic sewage-sludge biochar (MSSBpellet) and chicken-manure biochar (MCMB-pellet). The optimal preparation of both pellets was SA concentration $3 \%$ and crosslinking time $1 \mathrm{~h}$, whereas the ratios of bacteria to carrier were $1: 1$ and 1:3 for MSSB-pellet and MCMB-pellet, respectively. All resultant pellets of different colors were neutral $(\mathrm{pH}=$ 7.10-7.15), shaped as spheres with an average diameter of $4.3 \mathrm{~mm}(\Phi=4.32-4.34 \mathrm{~mm})$, and a greater density than water $\left(\rho=1.23-1.26 \mathrm{~g} / \mathrm{cm}^{3}\right)$ (Fig. 1).

\subsection{Biosorption characteristics}

\subsubsection{Effect of $\mathrm{pH}$}

The total biosorption capacity of immobilized pellet increased significantly when the initial $\mathrm{pH}$ increased from 2.0 to 6.0, whereas it decreased with the pH increasing from 6.0 to 8.0 (Fig. 2A). This indicated the three immobilized pellets reached the maximum biosorption capacity at $\mathrm{pH} 6.0$, during which the biosorption process was affected by the initial $\mathrm{pH}$ because of its effect on the surface charge of biosorbent (Fig. 2B). In addition, the biosorption capacity of immobilized bacteria were much higher than free bacteria under the $\mathrm{pH}$ range studied, it suggested that the immobilized bacteria pellets could have a great biosorption ability for the $\mathrm{Cd}^{2+}$ in solutions.

When initial $\mathrm{pH}<\mathrm{pH}_{\mathrm{IEP}}$ (between 2.0 and 3.0), the surface charge of immobilized pellets became positive because of the protonation of functional group (Fig. 2B), this caused electrostatic repulsion to positively charged $\mathrm{Cd}^{2+}$, resulting in the lowest biosorption capacity occurred at pH 2.0 (Fig. 2A). While initial pH > $\mathrm{pH}_{\mathrm{IEP}}$, the surface charge of biosorbent became negative and increased significantly with $\mathrm{pH}$ increasing from 3.0 to 6.0 , leading to the significant increase in biosorption capacity because of electrostatic attraction (Uchimiya, 2014; Cui et al., 2016). After that, the surface charge of biosorbents became 
stabilized in the pH range of 6.0 to 10.0, preserving the order of MRSB-pellet > MSSB-pellet > MCMB-pellet. Taken together, this suggested that MRSB-pellet had the highest biosorption capacity among these immobilized pellets, probably resulting from the greatest amount of negative charge.

Compared with the initial $\mathrm{pH}$, equilibrium $\mathrm{pH}$ increased slightly compared with initial pH (Fig. 2C), which were largely attributed to the addition of immobilized pellets. Compared to the blank system without $\mathrm{Cd}^{2+}$, equilibrium $\mathrm{pH}$ did not significantly change when the $\mathrm{Cd}^{2+}$ adsorbed onto biosorbents (Fig. 2D). This was related to the complexation with functional groups (eg., $-\mathrm{COOH},-\mathrm{OH})$, and precipitation with alkali ions (eg., $\mathrm{CO}_{3}{ }^{2-}, \mathrm{PO}_{4}{ }^{3-}$ ), accompanying with the release of $\mathrm{H}^{+}$into the solutions (Cui et al., 2016; Wang et al., 2018; Gao et al., 2019). In this context, it was implied that the mechanisms, including electrostatic interaction such as cation exchange, complexation, precipitation, or others could be involved in total biosorption process, these were in combination to affect the changes of solution $\mathrm{pH}$.

\subsubsection{Effect of culture time}

The biosorption rates of immobilized pellet were increased rapidly with increasing culture time, and then reached gradually a plateau within approximately 12,16 and $20 \mathrm{~h}$ under the initial $\mathrm{Cd}^{2+}$ concentration of 20,50 and $100 \mathrm{mg} / \mathrm{L}$, respectively. The biosorption with free bacteria took shorter hours to obtain the maximum biosorption capacity (Fig. 3A1, B1 and C1). This was probably attributed to the high complexity of biosorption process by immobilized pellet, during which the $\mathrm{Cd}^{2+}$ was quickly attached onto the biosorbent surface firstly, including magnetic biochar carrier and bacteria, and then was slowly adsorbed into the magnetic biochar internal or transferred into the bacterial protoplast, thus causing the delay to equilibration (Wen et al., 2018). Comparatively, such equilibrium was taken a much longer time than that of many previous reports that equilibration time were usually less than $2 \mathrm{~h}$, because these biosorption by microorganism immobilization using non-growing cells reached equilibrium more rapidly than that of growing cells (Tsekova et al., 2010; Ma et al., 2015; Letnik et al., 2017). In addition, the biosorption of immobilized bacteria was clearly more effective than free bacteria in all cases, and at the initial $\mathrm{Cd}^{2+}$ concentration of $100 \mathrm{mg} / \mathrm{L}$ (Fig. 3C1), the highest biosorption capacity of $51.53 \mathrm{mg} / \mathrm{g}$ achieved with MRSB-pellet was about 2.5-fold higher than that of free bacteria $(20.15 \mathrm{mg} / \mathrm{g})$. This enhancement by immobilized bacteria might be resulted from the simultaneous adsorption and bioaccumulation by magnetic biochar and bacteria, respectively.

Bacterial cells were more active in the exponential and stationary phase than lag and death phase, which would increase total biosorption of $\mathrm{Cd}^{2+}$ by enhancing cellular accumulation (Huang et al., 2014). Previous results have showed that the maximum uptake of $\mathrm{Cd}^{2+}$ for free microbial cells occurred at approximately the stationary phase (Andrès et al., 2000; El-Helow et al., 2000; Yilmaz and Ensari, 2005). In this work, cell number first increased during the exponential phase (immobilized bacteria: 0-20 h; free bacteria: $0-16 \mathrm{~h}$ ), and reached a plateau within the stationary phase (immobilized bacteria: $20-30 \mathrm{~h}$; free bacteria: 16-20 h), followed by a period of decrease only for free bacteria (Fig. 3A2, B2 and C2). It was evident that the magnetic biochar used as immobilized carrier would be favorable for the bacterial 
growth, since it increased the adaptability of the cells to the stressful environment such as $\mathrm{Cd}^{2+}$, thereby resulting in the increase in total biosorption capacity.

\subsubsection{Effect of initial $\mathrm{Cd}^{2+}$ concentration}

Total biosorption capacity increased rapidly with increasing initial $\mathrm{Cd}^{2+}$ concentration, followed by a plateau for immobilized and free bacteria (Fig. 4A). For immobilized bacteria, the highest biosorption capacities were 93.02, 68.02 and $63.95 \mathrm{mg} / \mathrm{g}$ at the initial $\mathrm{Cd}^{2+}$ concentration of $180 \mathrm{mg} / \mathrm{L}$ for MRSBpellet, MSSB-pellet, and CMB-pellet, which were almost 2.7, 2.0 and 1.8 times of free bacteria, respectively $\left(34.69 \mathrm{mg} / \mathrm{g}\right.$ at initial $\mathrm{Cd}^{2+}$ concentration of $\left.120 \mathrm{mg} / \mathrm{L}\right)$. Meanwhile, cell number and metabolic activity were expected to decrease with increasing initial $\mathrm{Cd}^{2+}$ concentration, which suggested that total biosorption was critically linked to cell viability and activity (Fig. 4B and C). Furthermore, bacterial number and activity was kept in the order of MRSB-pellet > MSSB-pellet > MCMB-pellet > free bacteria, this was consistent with the tendency of their biosorption capacities (Fig. 4A), suggesting that greater surface area of magnetic biochar carrier resulted in better bacterial growth to have higher biosorption capacity (Table S1). In addition, these maximum capacities were also comparable to the values (4.05-60.24 mg/g) calculated from Langmuir model regarding on the removal of $\mathrm{Cd}^{2+}$ from aqueous solution by microorganism immobilization, despite these studies were not conducted under culture conditions (Mahmoud et al., 2016; Letnik et al., 2017; Naskar and Bera, 2018). Even in the presence of $\mathrm{NaN}_{3}$, an ATPase inhibitor, immobilized bacteria persistently kept strong biosorption capacity for $\mathrm{Cd}^{2+}$ with the ranges of maximum biosorption capacity between 43.29 and $71.63 \mathrm{mg} / \mathrm{g}$, but free bacteria were significantly inhibited to the $\mathrm{Cd}^{2+}$ uptake of $4.68 \mathrm{mg} / \mathrm{g}$ (Fig. 4D). This further highlighted the obvious superiority of immobilized bacteria by magnetic biochar to the removal of $\mathrm{Cd}^{2+}$ from the solutions.

During the biosorption process, adsorption sites on the biosorbent surface were more easily to be occupied when the initial $\mathrm{Cd}^{2+}$ concentration was low, and the bioaccumulation by growing bacteria was inhibited insignificantly, thereby resulting in the significant increase in total biosorption. While initial $\mathrm{Cd}^{2+}$ concentration was increasing, biosorption sites were gradually achieved to saturation, and bacterial growth was greatly inhibited, thus the total biosorption reached the maximum values little by little (Shen et al., 2017). Similar observation that the energetically less favorable sites became involved with increasing $\mathrm{Cd}^{2+}$ concentration, was also reported by many researchers (Hou et al., 2013; Huang et al., 2013, Wan et al., 2018). In the presence of $\mathrm{NaN}_{3}$ inhibition, bacterial cells would probably die in the biosorption, which caused the significant decrease in total biosorption capacity, and it was expectedly delayed to the equilibration for immobilized bacteria. These further suggested that the monstrous complexity of biosorption mechanisms for immobilized bacteria to dominant the total biosorption process.

For immobilized bacteria, magnetic biochar carrier could decrease efficiently the $\mathrm{Cd}^{2+}$ concentration in liquid medium at the first moment, reducing the damage to growing bacteria within immobilized pellet, while free bacterial cells were naked and probably died when confronted with highly toxic $\mathrm{Cd}^{2+}$. Moreover, 
magnetic biochar was believed to provide shelter for the microorganism due to its pore structures, thereby prolonging the survival of immobilized bacteria in the stressful environment. Similar result was also reported by Shen et al. (2017), who demonstrated that the bioaccumulation of viable microalgae was probably due to preemptive interaction between biochar and $\mathrm{Cd}^{2+}$ to decrease the metal concentration in the solution, bringing it to a bioaccumulation-enabled level for microalgae. Besides this, there seemed to another possible explanation that the protect effect of magnetic field to increase the numbers of viable cells, thus resulting in the increase of total biosorption (Shen et al., 2017). Taken together, it was thus more attractive to use adsorption carrier such as magnetic biochar to improve the overall biosorption, because cell immobilization carrier with high adsorptive capacity could create carrier-adsorbed pollutants, and magnetic field could increase the numbers of viable cell, thereby protecting the bacteria against deleterious effect of $\mathrm{Cd}^{2+}$. Therefore, it suggested that immobilized pellet could be an efficient biosorbent for the removal of $\mathrm{Cd}^{2+}$ from aqueous solution, and the mechanisms were discussed below on a basis of qualitative and quantitative analysis.

\subsection{Biosorption mechanisms \\ 3.3.1. SEM-EDS observations}

Before the biosorption, immobilized bacterial biosorbent was spherical, and bacterial cells could largely distribute on the surface of magnetic biochar, since most of bacterial cells preferentially proliferated onto the surface due to the abundant supply of nutrients from liquid medium (Fig. 5). Meanwhile, the main energy biosorption elements of $\mathrm{C}, \mathrm{O}, \mathrm{Ca}$ and $\mathrm{Na}$ were also detected in the EDS spectra. This implied that oxygen-containing functional groups such as $-\mathrm{OH}$ and $-\mathrm{COOH}$ might be involved in the complexation mechanism, and exchangeable ions such as $\mathrm{Ca}^{2+}$ and $\mathrm{Na}^{+}$might play a role in the ion-exchange mechanism, both of which were responsible for the $\mathrm{Cd}^{2+}$ biosorption by immobilized pellet. Besides, the EDS spectra confirmed Fe and Cd elements presented on the surface of immobilized pellets, it was resulted from the preparation of magnetic biochar carrier, and the interaction between adsorbents and adsorbates, respectively. After the biosorption, immobilized pellets evidently became hollowed and irregular. This morphological shrinkage could be deemed as one of adaptive response to the stressful environment, which have been reported by some researchers demonstrating that the reduction of cell surface area was able to decrease the toxic effect of $\mathrm{Cd}^{2+}$ (Neumann et al., 2005; Nithya et al., 2011; Huang et al., 2014).

\subsubsection{FTIR and XRD studies}

In FTIR analysis, the broad peaks near $3392 \mathrm{~cm}^{-1}$ (MRSB-pellet), $1033 \mathrm{~cm}^{-1}$ (MSSB-pellet) and $1031 \mathrm{~cm}^{-}$ ${ }^{1}$ (MCMB-pellet) changed distinctly, representing $-\mathrm{OH}$ vibrations of hydroxyl groups (Fig. 6A). The bands at $2933 \mathrm{~cm}^{-1}$ (MRSB-pellet), $2932 \mathrm{~cm}^{-1}$ (MSSB-pellet), and $1421 \mathrm{~cm}^{-1}$ (MCMB-pellet) were connected to the stretching vibration of $-\mathrm{CH}$ groups (Li et al., 2017). The peaks around $1081 \mathrm{~cm}^{-1}$ (MRSB-pellet), 1727 $\mathrm{cm}^{-1}$ (MSSB-pellet), and $1613 \mathrm{~cm}^{-1}$ (MCMB-pellet) suggested the involvement of $\mathrm{C}=0$ of carboxyl groups in the metal ions binding (Cui et al., 2016). The peaks around $892 \mathrm{~cm}^{-1}$ (MRSB-pellet), $820 \mathrm{~cm}^{-1}$ 
(MSSB-pellet), and $819 \mathrm{~cm}^{-1}$ (MCMB-pellet) depicted the vibration of the $\mathrm{\gamma}-\mathrm{CH}$ of furans and the $\beta$-rings of pyridines (Uchimiya et al., 2010). Moreover, the peaks at $2160 \mathrm{~cm}^{-1}$ (MRSB-pellet), $2163 \mathrm{~cm}^{-1}$ (MSSBpellet), and $2167 \mathrm{~cm}^{-1}$ (MCMB-pellet) represented the $-\mathrm{CN}$ stretching vibration (Yu et al., 2018). In combination, it was implied that the complexation played an important role in total biosorption process, since the FTIR spectra after biosorption changed significantly. Moreover, the functional groups such as $\mathrm{OH},-\mathrm{CH}, \mathrm{C}=\mathrm{O},-\mathrm{CN}$ and $\mathrm{C}=\mathrm{C}$, could be responsible for the complexation of $\mathrm{Cd}^{2+}$ by immobilized pellets.

In XRD analysis (Fig. 6B), the cadmium precipitates were primarily composed of $\mathrm{CdCO}_{3}, \mathrm{Cd}_{3}\left(\mathrm{PO}_{4}\right)_{2}$, $\mathrm{CdSiO}_{3}, \mathrm{CdS}, \mathrm{Cd}(\mathrm{OH})_{2}$, and $\mathrm{CdP}_{2}$ (Khan et al., 2016; Huang et al., 2020b), in which $\mathrm{CdCO}_{3}$ and $\mathrm{Cd}_{3}\left(\mathrm{PO}_{4}\right)_{2}$ could be attributed to the concentration of exchangeable $\mathrm{CO}_{3}{ }^{2-}$ and $\mathrm{PO}_{4}{ }^{3-}$ in magnetic biochars (Table S1). The precipitation of $\mathrm{CdSiO}_{3}$ was probably due to the presence of silicates such as $\mathrm{K}_{2} \mathrm{SiO}_{3}$, this was also implied by FTIR observation that the bands between $700-500 \mathrm{~cm}^{-1}$ suggested the stretching vibration of Si-O-Si fractions. Similarly, the precipitate CdS was attributed to the existence of S-containing compound such as $\mathrm{Na}_{2} \mathrm{~S}$. While the unfamiliar precipitate of $\mathrm{CdP}_{2}$ could be resulted from the reaction between the $\mathrm{Cd}$ speciation and reduction state of phosphate (Demirbas, 2004). Despite this, the overall intensity of peaks changed insignificantly after biosorption for immobilized pellets, suggesting that the precipitation played a role but not an important role during total biosorption process.

\subsubsection{Relative contribution of each mechanism}

For MRSB-pellet, the desorption percentages of $\mathrm{Cd}^{2+}$ by $\mathrm{NH}_{4} \mathrm{NO}_{3}$ were the biggest fraction (44.04\%-46.54\%), followed by the fraction by EDTA-Na 2 (26.76\%-29.16\%). This suggested that ionexchange was always the predominant mechanism, followed by the complexation in total biosorption (Fig. 7). Similarly, ion-exchange was recognized as one of predominant mechanisms because of the replacement of light metal ions such as $\mathrm{K}^{+}, \mathrm{Ca}^{2+}, \mathrm{Na}^{+}$and $\mathrm{Mg}^{2+}$ by metal ions (Markou et al., 2015; Li et al., 2017). In comparison, the desorption percentages of EDTA-Na 2 were the biggest fraction for MSSBpellet and MCMB-pellet, accounting for $41.19 \%-45.12 \%$ and $41.29 \%-46.45 \%$, followed by the fraction by $\mathrm{NH}_{4} \mathrm{NO}_{3}$ eluted, with their contribution proportions were $34.98 \%-36.05 \%$ and $31.23 \%-36.75 \%$, respectively.

These highlighted the most important role of complexation with functional groups among these mechanisms, followed by the ion-exchange in total biosportion. Such decrease in the importance of ionexchange was probably attributed to lower concentrations of dissolved inorganic component in both magnetic biochars, such as $\mathrm{K}^{+}, \mathrm{Ca}^{2+}, \mathrm{Na}^{+}$and $\mathrm{Mg}^{2+}$ (Table S1). Indeed, the complexation was primarily responsible for total biosorption, owing to the presence of many functional groups including $-\mathrm{OH},-\mathrm{CH}, \mathrm{C}=$ 0 , $-\mathrm{CN}$ and $\mathrm{C}=\mathrm{C}$, as also supported by FTIR analysis (Fig. 6A). Taken together, the total biosorption by immobilized pellets was mainly governed by complexation and ion-exchange, since their contribution proportion of both mechanisms were higher than 70\% under all conditions (73.20\%-74.19\%). This was in accordance with the findings in the chitosan bead immobilizing Pseudomonas Putida cells, where both complexation and ion-exchange were identified as the main mechanisms for $\mathrm{U}(\mathrm{VI})$ biosorption (Sohbatzadeh et al., 2017). 
The importance of precipitation in all immobilized pellets was comparably tiny, because the contribution percentages of total biosorption were low. This phenomenon could be partly explained by the XRD analysis, where the intensity of peaks showed no significant changes after biosorption (Fig. 6B). Likewise, physical adsorption was an insignificant mechanism for all immobilized pellets, since this mechanism represented less than $10.91 \%$ of total biosorption at all conditions. This was consistent with the results reported by the researchers investigating the metal biosorption by immobilized microbial cells (Sohbatzadeh et al., 2017) and microalgae (Nasreen et al., 2008). In this context, intracellular accumulation by active bacterial cells certainly played a certain role in total biosorption, although their contribution proportions were low. It was proved that the protective effect of magnetic biochar on the live bacteria was pronounced in mobilized pellet, because bacterial cells could maintain intracellular $\mathrm{Cd}^{2+}$ level below a toxic threshold for the control of metal homeostasis to grow better in the highly stressful environment.

Apart from the five mechanisms above, other possible mechanisms such as electrostatic attraction and Cr-coordination, had also been proposed in the biosorption of $\mathrm{Cd}^{2+}$ (Yuan et al.., 2020; Zhu, et al., 2020; Wang et al., 2021). In fact, electrostatic attraction was responsible for the total biosorption in the present work. However, it was not considered separately when calculating the contribution proportion of each mechanism to total biosorption, since this mechanism could be simultaneously participated in ionexchange, complexation, and precipitation mechanisms, leading to the impossibility in accurate calculation of its relative contribution proportion. Likewise, C $\pi$-coordination could be also involved in total biosorption by immobilized pellet. Given that this mechanism was closely related to the functional groups of biosorbents, it made sense to assign this mechanism to the complexation for better determinate the relative distribution of biosorption mechanisms. In summary, total biosorption of $\mathrm{Cd}^{2+}$ by immobilized pellet was primarily driven by ion-exchange and complexation, to which chemical precipitation and physical adsorption also contributed, though intracellular accumulation was of minor importance.

\section{Conclusions}

Total biosorption by immobilized pellet reached saturation within 12-20 $\mathrm{h}$ at an optimal pH of 6.0, obtaining the maximum capacity of $93.02,68.02$ and $63.95 \mathrm{mg} / \mathrm{g}$ for MRSB-pellet, MSSB-pellet, and MCMB-pellet, respectively. The biosorption by these immobilized bacteria was superior to free bacteria for the metal removal, even when confronted with $\mathrm{NaN}_{3}$ inhibition. Such enhancement in biosorption capacity was resulted from simultaneous adsorption and bioaccumulation by magnetic biochar carrier and bacteria, respectively. The mechanisms responsible for the $\mathrm{Cd}^{2+}$ biosorption by immobilized pellet included physical adsorption, ion-exchange, complexation, precipitation, and intracellular accumulation, all of which might have taken place independently and synergistically. Both ion-exchange and complexation dominated the overall biosorption, followed by chemical precipitation and physical adsorption, whereas intracellular accumulation was comparably tiny in these mechanisms. These suggested that a matrix of viable microorganisms immobilized on magnetic biochar could have a great potential to remove $\mathrm{Cd}^{2+}$ from a liquid medium. 


\section{Declarations}

\section{Acknowledgements}

This research was financially supported by the Basic and Applied Research Program of Guangdong Province (2019A1515012187), the National Natural Science Foundation of China (No. 42007323), the Shenzhen Science \& Technology Project (SZIITWDZC2021A01),the High-level Professionals and Innovative Teams (No. SZIIT2019KJ024; No. SZIIT2019KJ007).

\section{Author contribution}

Dan Peng conceived and designed the ideas to develop in the article. Min Deng analyzed data and wrote the manuscript with help of Kai Li providing the experimental sets. Yu-Jian Yan and Fei Huang conducted the SEM-EDS, FTIR, XRD tests for the biochars studied in this study. All authors contributed to the final version of this manuscript.

\section{Data availability}

All data generated or analyzed during this study are included in this published article.

Ethics approvalNot applicable.

Consent to participateNot applicable.

Consent for publication Not applicable.

Competing interests The authors declare no competing interests.

\section{References}

1. Andrès, Y., Thouand, G., Boualam, M., Mergeay, M., 2000. Factors influencing the biosorption of gadolinium by micro-organisms and its mobilization from stand. Appl. Microbiol. Biotechnol. 54, 262-267.

2. Barquilha, C.E.R., Cossich, E.S., Tavares, C.R.G., Silva, E.A., 2017. Biosorption of nickel(II) and copper(II) ions in batch and fixed-bed columns by free and immobilized marine algae Sargassum sp. J. Clean. Prod., 150, 58-64.

3. Chojnacka, K., 2010. Biosorpiton and bioaccumulation-the prospects for practical applications. Environ. Int. 36, 299-307.

4. Cui, X., Fang, S., Yao, Y., Li, T., Ni, Q., Yang, X., He, Z., 2016. Potential mechanisms of cadmium removal from aqueous solution by Canna indica derived biochar. Sci. Total Environ. 562, 517-525.

5. Demirbas, A., 2004. Effect of temperature and particle size on bio-char yield from pyrolysis of agricultural residues. J. Anal. Appl. Pyrol. 72, 243-248. 
6. El-Helow, E.R., Sabry, S.A., Amer, R.M., 2000. Cadmium biosorption by a cadmium resistant strain of Bacillus thuringiensis: regulation and optimization cell surface affinity for metal cations. Biometals. 13, 273-280.

7. Gao, L.Y., Deng, J.H., Huang, G.F., Li, K., Cai, K.Z., Liu, Y., Huang, F., 2019. Relative distribution of $\mathrm{Cd}^{2+}$ adsorption mechanisms on biochars derived from rice straw and sewage sludge. Bioresour. Technol. 272, 114-122.

8. Godt, J., Scheidig, F., Grosse-Siestrup, C., Esche, V., Brandenburg, P., Reich, A., Groneberg, D.A., 2006. The toxicity of cadmium and resulting hazards for human health. J. Occup. Med. Toxicol. 1, 22.

9. Huang, F., Dang, Z., Guo, C.L., Lu, G.N., Gu, R.R., Liu, H.J., Zhang, H., 2013. Biosorption of Cd(II) by live and dead cells of Bacillus cereus RC-1 isolated from cadmium-contaminated soil. Colloids Surf. B. 107, 11-18.

10. Huang, F., Guo, C.L., Lu, G.N., Yi, X.Y., Zhu, D.L., Dang, Z., 2014. Bioaccumulation characterization of cadmium by growing Bacillus cereus RC-1 and its mechanism. Chemosphere, 109, 134-142.

11. Huang, F., Gao, L.L., Wu, R.R., Wang, H., Xiao, R.B., 2020a. Qualitative and quantitative characterization of adsorption mechanisms for $\mathrm{Cd}^{2+}$ by silicon-rich biochar. Sci. Total Environ. 731, 139163.

12. Huang, F., Li, K., Wu, R.R., Yan, Y.J., Xiao, R.B., 2020b. Insight into the $\mathrm{Cd}^{2+}$ biosorption by viable Bacillus cereus RC-1 immobilized on different biochars: roles of bacterial cell and biochar matrix. J. Clean. Prod., 272, 122743.

13. Huang, F., Zhang, S.M., Wu, R.R., Zhang, L., Wang, P., Xiao, R.B., 2021. Magnetic biochars have lower adsorption but higher separation effectiveness for $\mathrm{Cd}^{2+}$ from aqueous solution compared to nonmagnetic biochars. Environ. Pollut. 275, 116485.

14. Hou, D., Shen, X., Luo, Q., He, Y., Wang, Q., Liu, Q., 2013. Enhancement of the diesel oil degradation ability of a marine bacterial strain by immobilization on a novel compound carrier material. Marin Pollut. Bullet. 67, 146-151.

15. Khan, Z., Rehman, A., Hussain, S.Z., 2016. Resistance and uptake of cadmium by yeast, Pichia hampshirensis 4Aer, isolated from industrial effluent and its potential use in decontamination of wastewater. Chemosphere. 159, 32-43.

16. Letnik, I., Avrahami, R., Port, R., Greiner, A., Zussman, E., Stefan Rokem, J., Greenblatt, C., 2017. Biosorption of copper from aqueous environments by Micrococcus luteus in cell suspension and when encapsulated. Int. Biodeterior. Biodegrad. 116, 64-72.

17. Li, X., Dai, L., Zhang, C., Zeng, G., Liu, Y., Zhou, C., Xu, W., Wu, Y., Tang, X., Lan, S., 2017. Enhanced biological stabilization of heavy metals in sediment using immobilized sulfate reducing bacteria beads with inner cohesive nutrient. J. Hazard. Mater. 324, 340-347.

18. Liu, S.H., Zeng, Z.T., Niu, Q.Y., Xiao, R., Zeng, G.M., Liu, Y., Tao, J.J., 2019. Influence of immobilization on phenanthrene degradation by Bacillus sp. P1 in the presence of Cd(II). Sci. Total Environ. 665, 1279-1287. 
19. Luo, S., Xia, X., Xi, Q., Wan, Y., Chen, L., Zeng, G., Liu, C., Guo, H., Chen, J., 2011. Enhancement of cadmium bioremediation by endophytic bacterium Bacillus sp. L14 using industrially used metabolic inhibitors (DCC or DNP). J. Hazard. Mater. 190, 1079-1082.

20. Ma, X., Cui, W., Yang, L., Yang, Y., Chen, H., Wang, K., 2015. Efficient biosorption of lead(II) and cadmium(II) ions from aqueous solutions by functionalized cell with intracellular $\mathrm{CaCO}_{3}$ mineral scaffolds. Bioresour. Technol. 185, 70-78.

21. Mahmoud, M.E., Abdou A.E.H., Mohamed, S.M.S., Osman, M.M., 2016. Engineered staphylococcus aureus via immobilization on magnetic $\mathrm{Fe}_{3} \mathrm{O}_{4}$-phthalate nanoparticles for biosorption of divalent ions from aqueous solutions. J. Environ. Chem. Engineer. 4, 3810-3824.

22. Markou, D., Mitrogiannis, D., Celekli, A., Bozkurt, H., Georgakakis, D., Chrysikopoulos, C.V., 2015. Chrysikopoulos, Biosorption of $\mathrm{Cu}^{2+}$ and $\mathrm{Ni}^{2+}$ by Arthrospira platensis with different biochemical compositions. Chem. Eng. J. 259, 806-813.

23. Mohan, D., Kumar, H., Sarswat, A., Alexandrefranco, M., Pittman, C.U., 2014. Cadmium and lead remediation using magnetic oak wood and oak bark fast pyrolysis bio-chars. Chem. Eng. J. 236, 513528.

24. Naskar, A., Bera, D., 2018. Mechanistic exploration of $\mathrm{Ni}(\mathrm{II})$ removal by immobilized bacterial biomass and interactive influence of coexisting surfactants. Environ. Prog. Sustain. Energy, https://doi. org/10.1002/ep.12685.

25. Nasreen, A., Muhammad, I., Saeed Iqbal, A., Javed, I., 2008. Biosorption characteristics of unicellular green alga Chlorella sorokiniana immobilized in loofa sponge for removal of $\mathrm{Cr}(\mathrm{III})$. J. Environ. Sci. 20, 231-239.

26. Neumann, G., Veeranagouda, Y., Karegoudar, T.B., Sahin, Ö., Mäusezahl, I., Kabelitz, N., Kappelmeyer U., Heipieper, H.J., 2005. Cells of Pseudomonas putida and Enterobacter sp. adapt to toxic organic compounds by increasing the size. Extremophiles 9, 163-168.

27. Nithya, C., Gnanalakshmi, B., Pandian, S.K., 2011. Assessment and characterization of heavy metal resistance in Palk Bay sediment bacteria. Mar. Environ. Res. 71, 283-294.

28. Piccirillo, C., Pereira, S.I.A., Marques, A.P., Pullar, R.C., Tobaldi, D.N., Pintado, M.E., Castro, P.M., 2013. Bacteria immobilisation on hydroxyapatite surface for heavy metals removal. J. Environ. Manage. $121,87-95$.

29. Robalds, A., Naja, G.M., Klavins, M., 2016. Highlighting inconsistencies regarding metal biosorption. J. Hazard. Mater. 304, 553-556.

30. Sarma, S.J., Pakshirajan, K., 2011. Surfactant aided biodegradation of pyrene using immobilized cells of Mycobacterium frederiksbergense. Int. Biodeterior. Biodegrad. 65, 73-77.

31. Shen, Y., Li, H., Zhu, W., Ho, S.H., Yuan, W., Chen, J., Xie, Y., 2017. Microalgal-biochar immobilized complex: a novel efficient biosorbent for cadmium removal from aqueous solution. Bioresour. Technol. 244, 1031-1038. 
32. Shen, Y., Zhu, W., Li, H., Ho, S.H., Chen, J., Xie, Y., Shi, X., 2018. Enhancing cadmium bioremediation by a complex of water-hyacinth derived pellets immobilized with Chlorella sp. Bioresour. Technol. 257, 157-163.

33. Sohbatzadeh, H., Keshtkar, A.R., Safdari, J., Fatemi, F., 2017. Insights into the biosorption mechanisms of $\mathrm{U}(\mathrm{VI})$ by chitosan bead containing bacterial cells: A supplementary approach using desorption eluents, chemical pretreatment and PIXE-RBS analyses. Chem. Eng. J. 323, 492-501.

34. Tsekova, K., Todorova, D., Dencheva, V., Ganeva, S., 2010. Biosorption of copper(II) and cadmium(II) from aqueous solutions by free and immobilized biomass of Aspergillus niger. Bioresour. Technol. $101,1727-1731$.

35. Uchimiya, M., lima, I.M., Klasson, K.T., Chang, S., Wartelle, L.H., Rodgers, J.E., 2010. Immobilization of heavy metals ions ( $\mathrm{Cu}^{\prime \prime}, \mathrm{Cd}^{\prime \prime}, \mathrm{Ni}^{\prime \prime}$ and $\left.\mathrm{Pb}^{\prime \prime}\right)$ by broiler litter-derived biochars in water and soil. J. Agric. Food. Chem. 58, 5538-5544.

36. Uchimiva, M., 2014. Influence of pH, ionic strength, and multidentate ligand on the interaction of Cd" with biochars, ACS. Sustainable Chem. Eng. 2, 2019-2027.

37. Wan, S., Wu, J., Zhou, S., Wang, R., Gao, B., He, F., 2018. Enhanced lead and cadmium removal using biochar-supported hydrated manganese oxide (HMO) nanoparticles: behavior and mechanism. Sci. Total Environ. 616-617, 1298-1306.

38. Wang, R.Z., Huang, D.L., Liu, Y.G., Zhang, C., Lai, C., Zeng, G.M., Cheng, M., Gong, X.M., Wan, J., Luo, $\mathrm{H}_{.}, 2018$. Investigating the adsorption behavior and the relative distribution of $\mathrm{Cd}^{2+}$ sorption mechanisms on biochars by different feedstock. Bioresour. Technol. 261, 265-271.

39. Wang, H., Huang, F., Zhao, Z.L., Wu, R.R., Xu, W.X., Wang, P., Xiao, R.B., 2021. High-efficiency removal capacities and quantitative adsorption mechanisms of $\mathrm{Cd}^{2+}$ by thermally modified biochars derived from different feedstocks. Chemosphere 272, 129594.

40. Wen, X., Du, C., Zeng, G., Huang, D., Zhang, J., Yin, L., Tan, S., Huang, L., Chen, H., Yu, G., Hu, X., Lai, C., Xu, P., Wan, J., 2018. A novel biosorbent prepared by immobilized Bacillus licheniformis for lead removal from wastewater. Chemosphere 200, 173-179.

41. Yilmaz, E.I., Ensari, N.Y., 2005. Cadmium biosorption by Bacillus sirculans strain EB1. World J. Microbiol. Biotechnol. 21, 777-779.

42. Yu, W., Lian, F., Gui, G., Liu, Z., 2018. N-doping effectively enhances the adsorption capacity of biochar for heavy metal ions from aqueous solution. Chemosphere 193, 8-16.

43. Yuan, S., Hong, M., Li, H., Ye, Z., Gong, H., Zhang, J., Huang, Q., Tan, Z., 2020. Contributions and mechanisms of components in modified biochar to adsorb cadmium in aqueous solution. Sci. Total Environ. 733, 139320.

44. Zamani, H., Rakhshaee, R., Garakoui, S.R., 2018. Two contrary roles of $\mathrm{Fe}_{3} \mathrm{O}_{4}$ nanoparticles on kinetic and thermodynamic of Paclitaxel degradation by Citrobacter amalonaticus Rashtia immobilized on sodium alginate gel beads. J. Hazard. Mater. 344, 566-575. 
45. Zhang, K., Liu, Y., Luo,H., Chen, Q., Zhu, Z., Chen, J., Ji, L., Mo, Y., 2017. Bacterial community dynamics and enhanced degradation of di-n-octyl phthalate (DOP) by corncob-sodium alginate immobilized bacteria. Geoderma. 305, 264-274.

46. Zhu, X., Chen, B., Zhu, L., Xing, B., 2017. Effects and mechanisms of biochar-microbe interactions in soil improvement and pollution remediation: a review. Environ. Pollut. 227, 98-115.

47. Zhu, L., Tong, L., Zhao, N., Wang, X., Yang, X., Lv, Y., 2020. Key factors and microscopic mechanisms controlling adsorption of cadmium surface oxidized and aminated biochars. J. Hazard. Mater. 382, 121002.

\section{Tables}

\section{Table 1}

Orthogonal experiments of $\mathrm{Cd}^{2+}$ biosorption by the bacteria immobilized on different magnetic biochars.

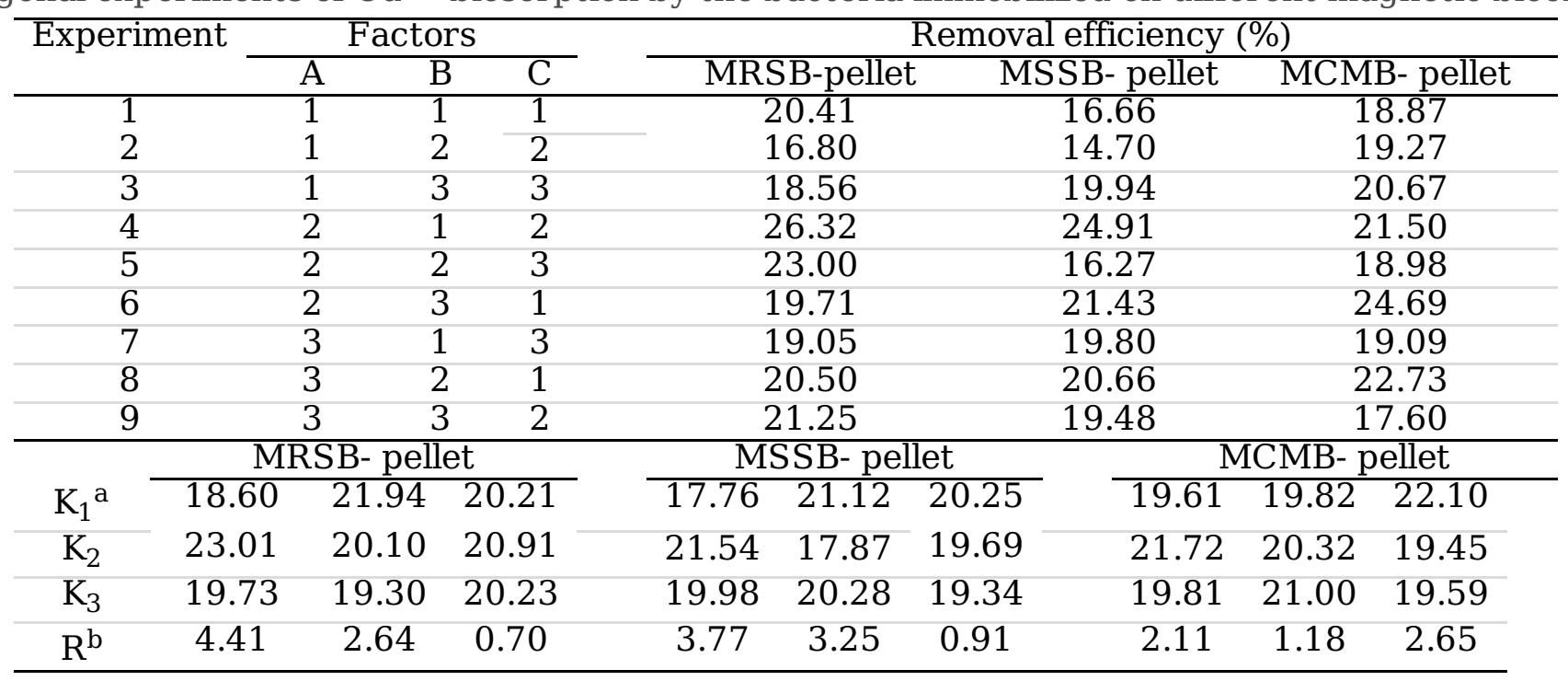

${ }^{a} K_{1}, K_{2}$ and $K_{3}$ represent mean value of metal removal at different factor levels 1, 2 and 3, respectively.

$\mathrm{b}$ represents the range of metal removal under different factors.

\section{Figures}




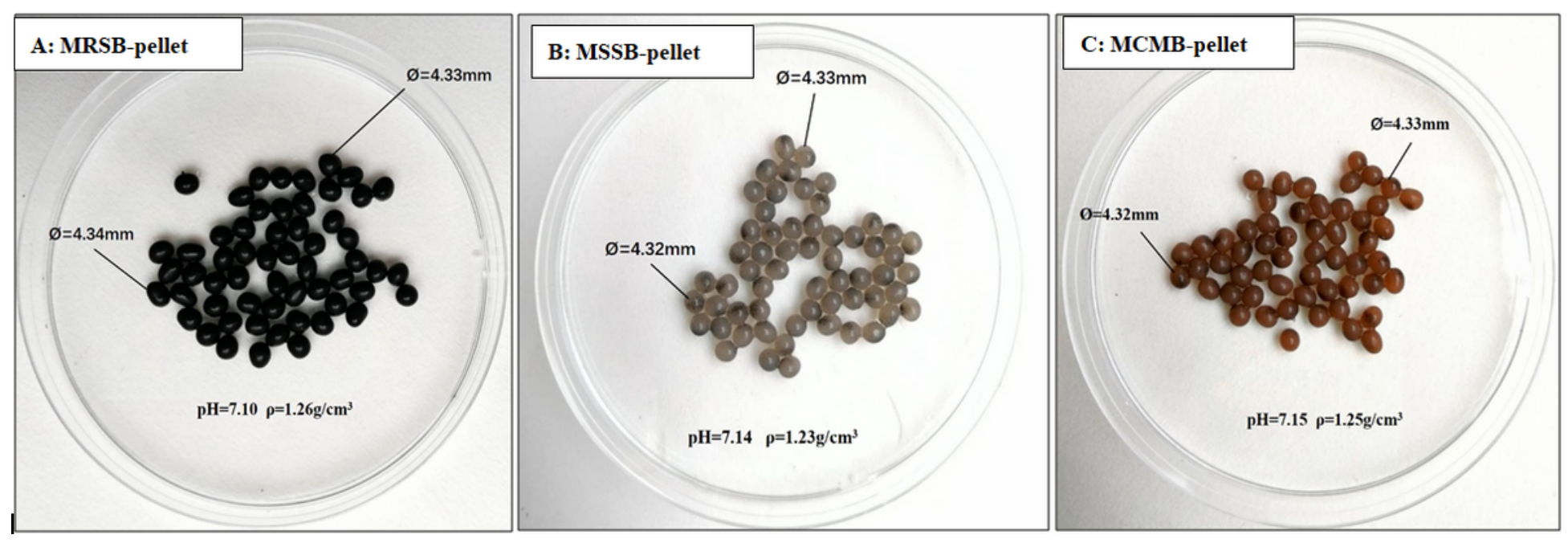

\section{Figure 1}

Pictures of immobilized bacterial pellets (A: MRSB-pellet, B: MSSB-pellet, C: MCMB-pellet). 

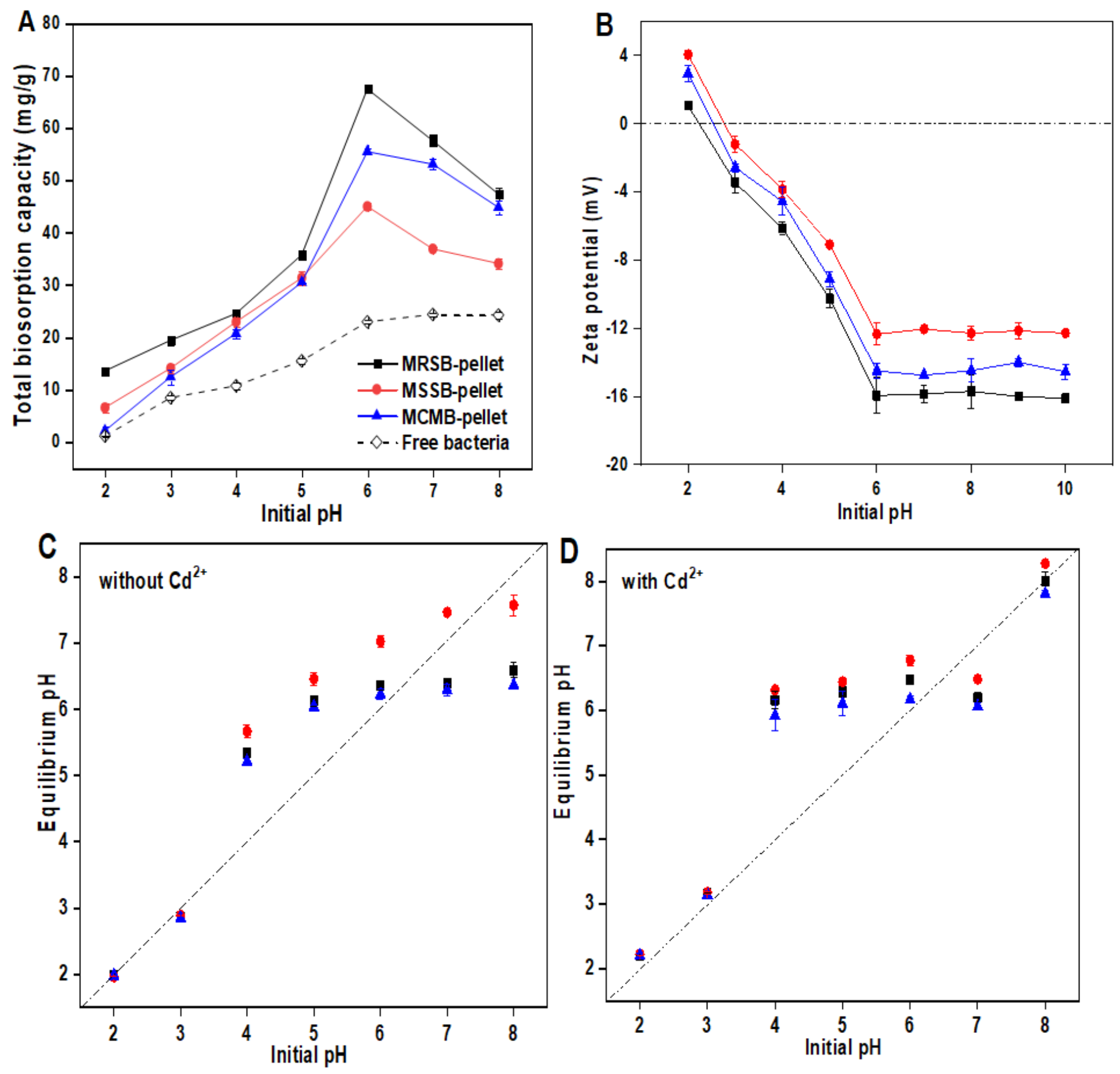

Figure 2

Effect of $\mathrm{pH}$ on the total $\mathrm{Cd} 2+$ biosorption capacity by immobilized bacteria and free bacteria (A).Zeta potential of immobilized pellets at different $\mathrm{pH}$ values $(\mathrm{B})$. Changes of $\mathrm{pH}$ in the mixed solution without $\mathrm{Cd} 2+(\mathrm{C})$ and with $\mathrm{Cd} 2+$ after equilibration (D). 

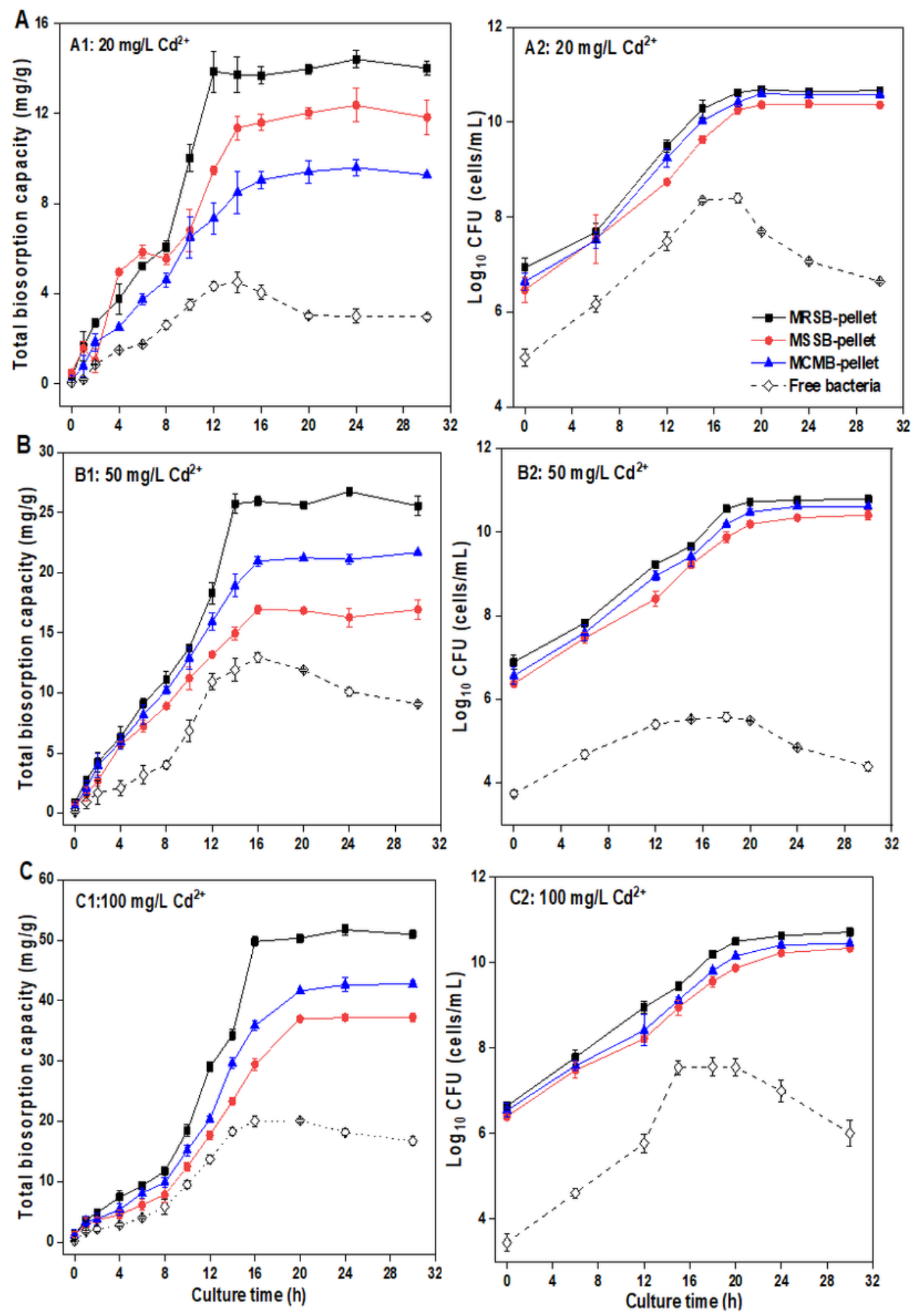

Figure 3

Effect of culture time on total biosorption capacity and cell numberby immobilized bacteria and free bacteria under three different initial $\mathrm{Cd} 2+$ concentrations (A1 and A2: $20 \mathrm{mg} / \mathrm{L} \mathrm{Cd} 2+; \mathrm{B} 1$ and B2: $50 \mathrm{mg} / \mathrm{L}$ Cd2+; C1 and C2: $100 \mathrm{mg} / \mathrm{L} \mathrm{Cd2+).}$ 

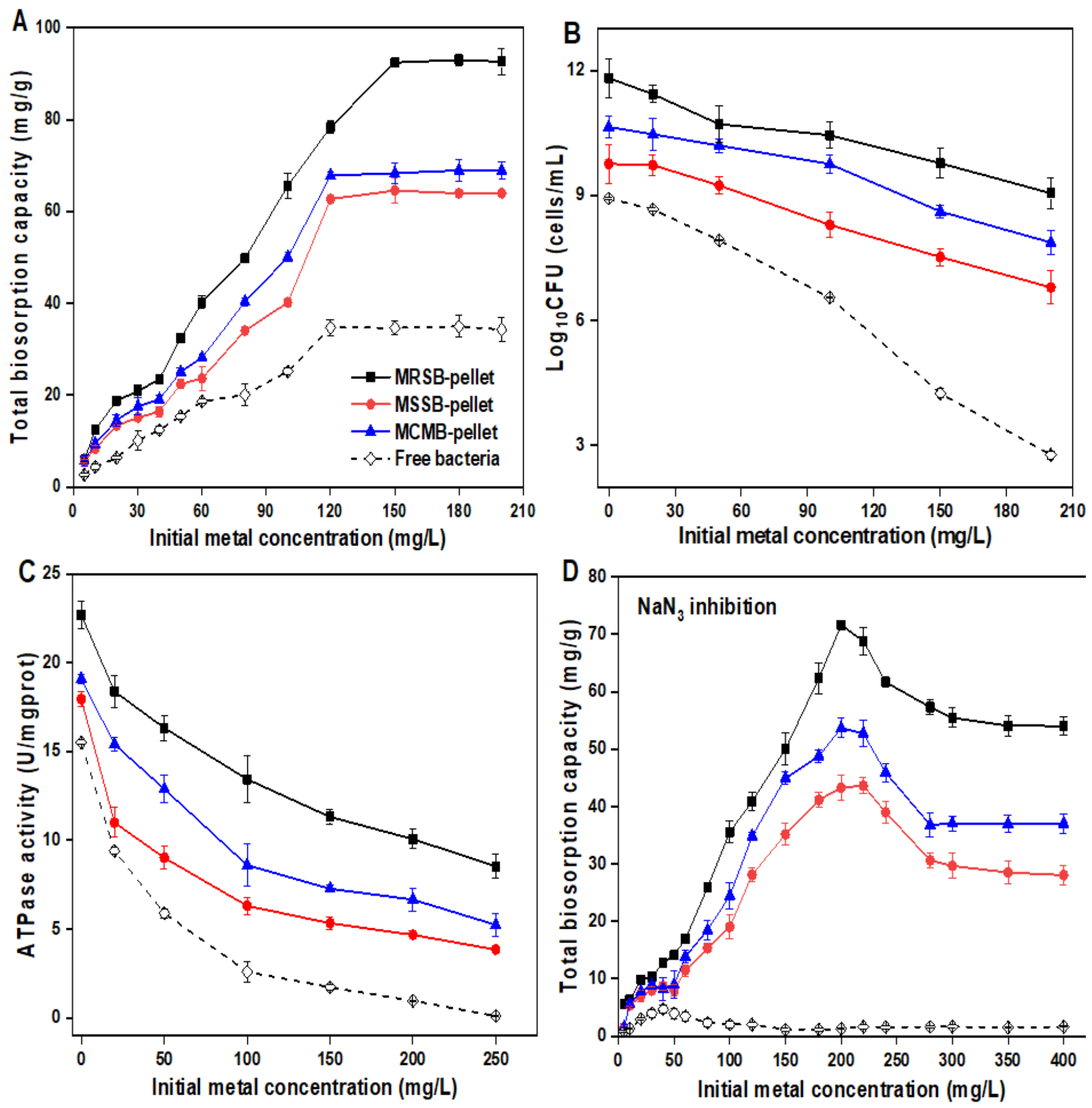

Figure 4

Effect of initial $\mathrm{Cd} 2+$ concentrations on total biosorption capacity by immobilized bacteria and free bacteria in the absence (A) and presence of NaN3(D). Effect of initial $\mathrm{Cd} 2+$ concentrations on thecell number (B)and ATPase activity (C)by immobilized bacteria and free bacteria. 

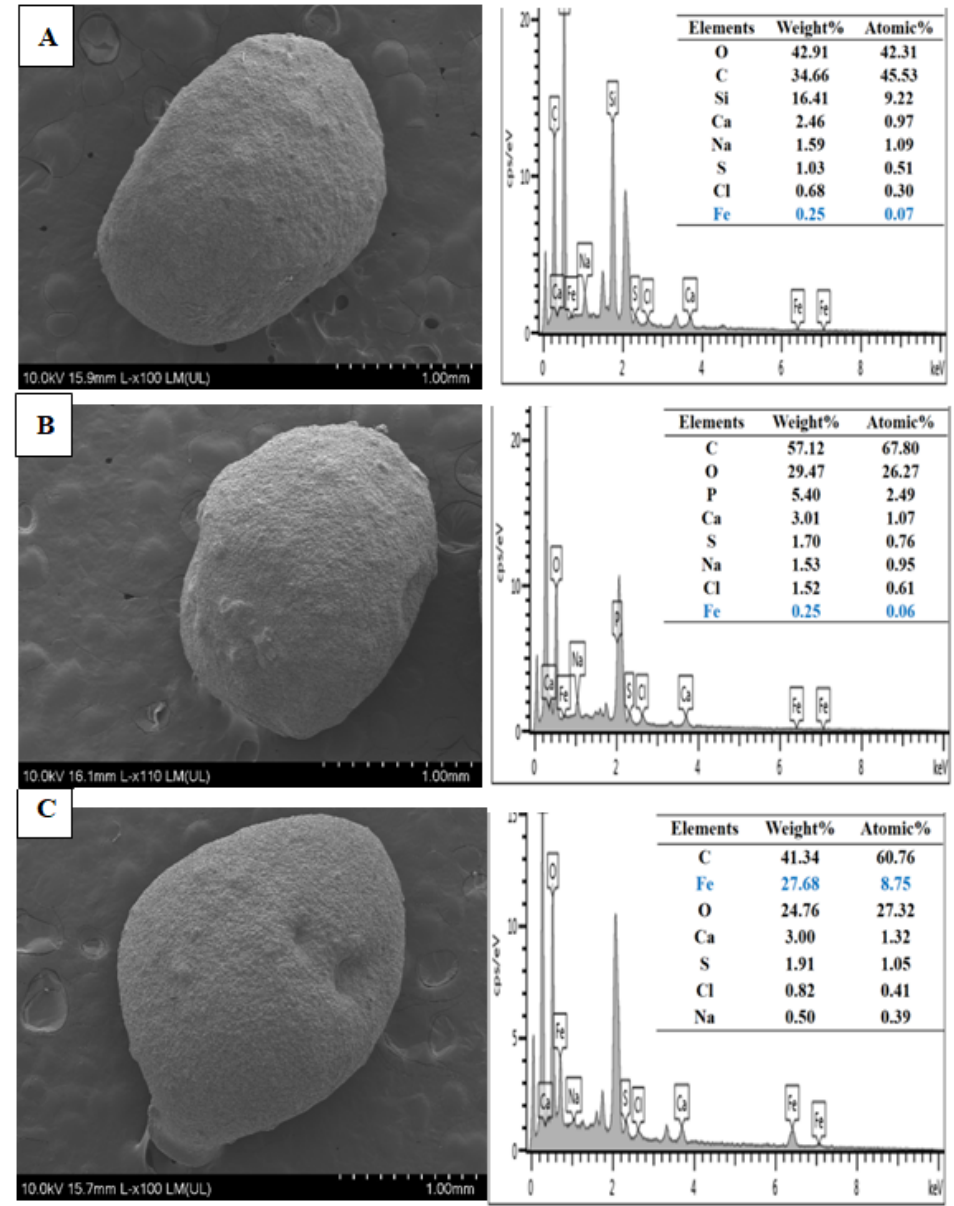
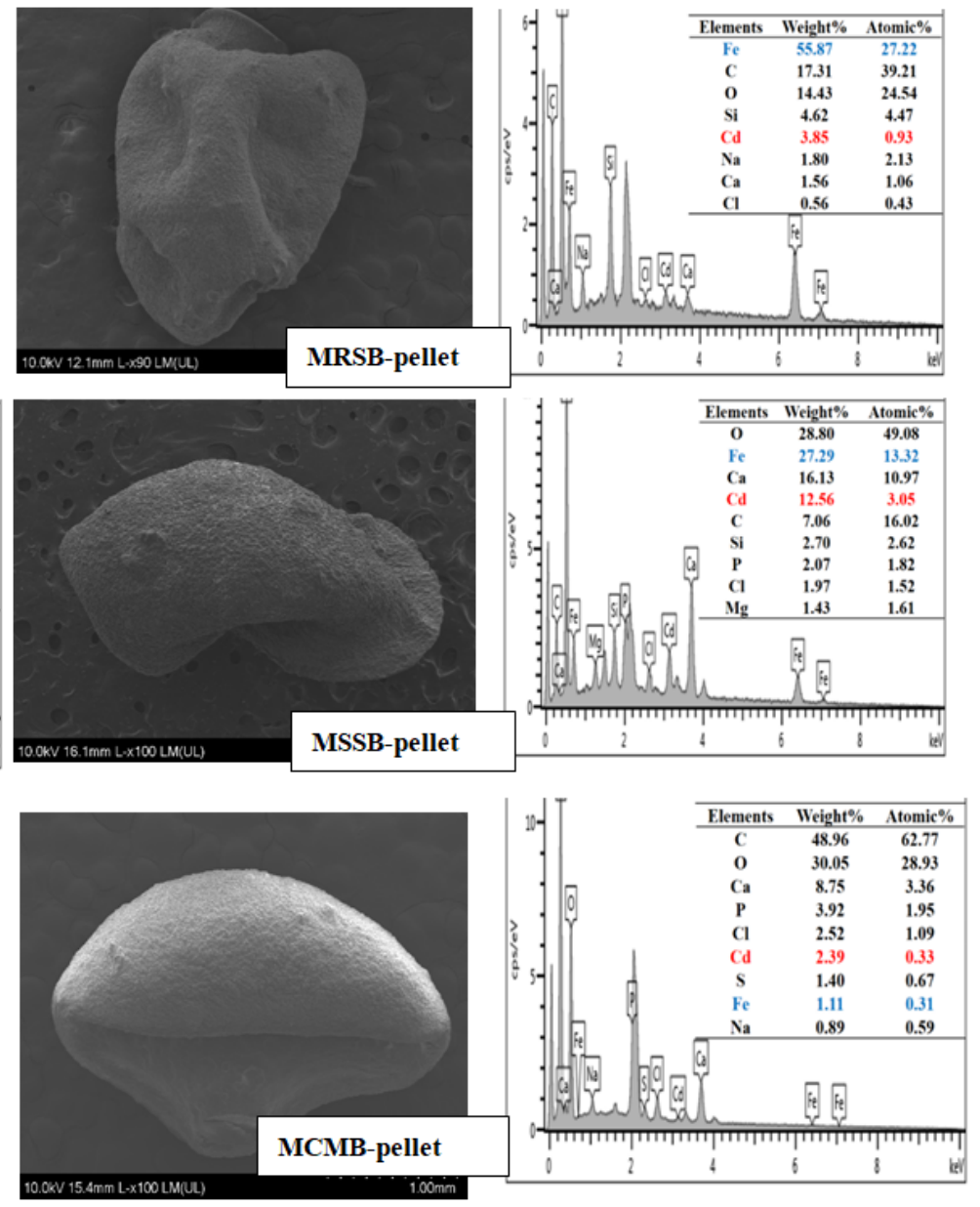

Figure 5

SEM images and corresponding EDS spectra of immobilized pellet before and afterCd2+ biosorption (A: MRSB-pellet, B: MSSB-pellet, C: MCMB-pellet). 


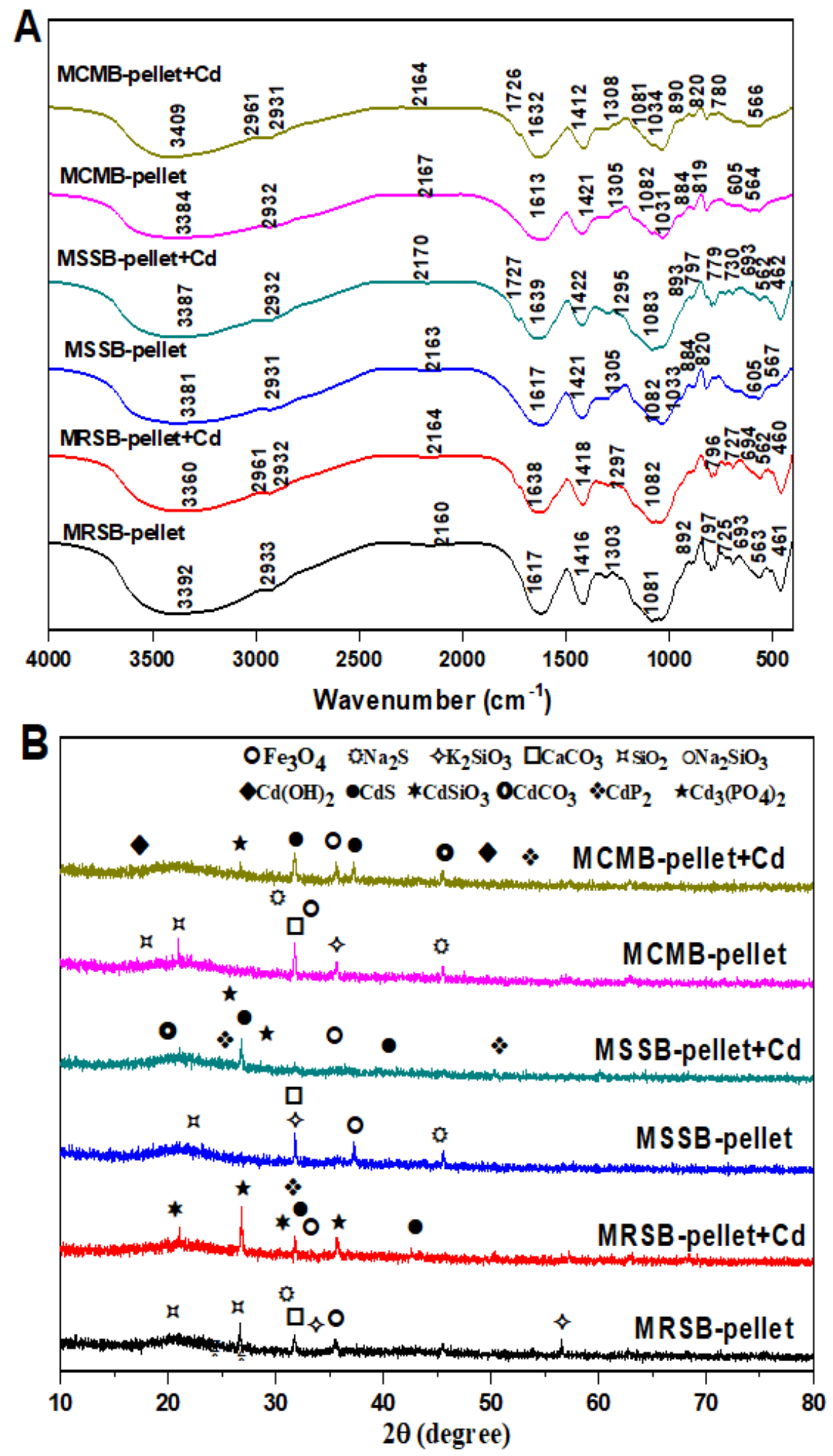

Figure 6

FTIR and XRD spectra of immobilized pelletbefore and after Cd2+ biosorption. 

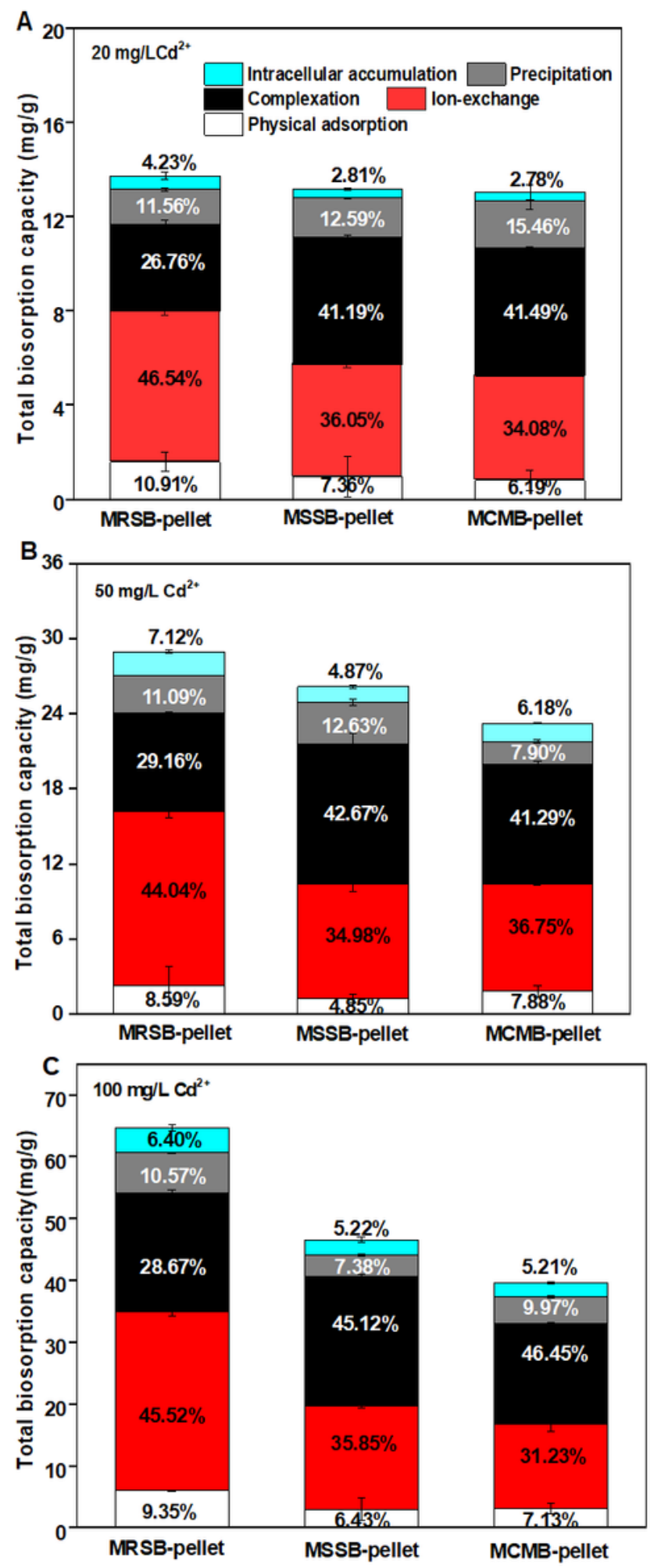

Figure 7

Relative contribution of involvedmechanism in total biosorptionby immobilized pelletunder different initial Cd2+ concentrations of $20 \mathrm{mg} / \mathrm{L}(\mathrm{A}), 50 \mathrm{mg} / \mathrm{L}(\mathrm{B})$ and $100 \mathrm{mg} / \mathrm{L}(\mathrm{C})$, respectively.

\section{Supplementary Files}


This is a list of supplementary files associated with this preprint. Click to download.

- Graphicalabstract.docx

- Tables1.docx

- Tables2.docx 